\title{
Child-Friendly Cities and Districts As Human Rights Protection in Indonesia's Decentralization Context
}

\author{
Fanny Tanuwijaya* \\ University of Jember, Indonesia
}

\section{Fiska Maulidian Nugroho \\ University of Jember, Indonesia}

\begin{abstract}
This paper aims to examine the implementation of the Child Friendly Cities and Districts in Indonesia, as part of the decentralized agenda of current Indonesian reform. Child protection has become one of the current problematic issues. This protection includes the effort to guarantee and ensure the right to live, grow, develop, and participate fully in realizing each child's future. The Indonesian government introduces regional child protection, it is ChildFriendly Cities and Districts as a part of the critical address responding to the issue to the extent the government provide a serious protection for the infant generation. Historically, the United Nations Children's Fund (UNICEF) initiated this concept, whose purpose was to aspire to children's rights through the goals, programs, policies, and local governance structures. To date, there remain many regional governments that do not have regulations on child-friendly cities or districts. This paper considers Indonesia's regions experiencing in regulating and implementing the child-friendly cities and districts that have become a benchmark for the other regions. In the end, this paper concludes that each region must regulate and implement the child-friendly cities with regional characteristics into a series of regional regulations, particularly preceded by the regional regulation.
\end{abstract}

KEYWORDS: Human Rights, Child Protection, Children Rights, Child-Friendly Cities.

Submitted: 20/04/2020 Reviewed: 20/06/2020 Revised: 15/08/2020 Accepted: 20/09/2020

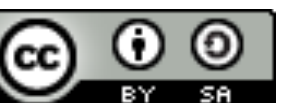

Copyright @ 2020 by Author(s)

This work is licensed under a Creative Commons Attribution-ShareAlike 4.0 International License. All writings published in this journal are personal views of the authors and do not represent the views of this journal and the author's affiliated institutions

* Corresponding authors' e-mail: fanny.tanuwijaya@unej.ac.id 


\section{INTRODUCTION}

Child protection ensures children their rights to live, grow, develop, and participate optimally based on human prestige and dignity. ${ }^{1}$ This protection aims to guarantee the children's rights are fulfilled, ${ }^{2}$ including in the extensive scope of education and health assurance. To this extent, it also encompasses the protection against sexual violence. Based on the figure released by the Indonesian Child Protection Commission (KPAI) in 20112016, there were eight types of child protection cases that are susceptible to children. They are social and child in danger situation, family and alternative nurture, religion and culture, civil right and participation, health and drugs, education, pornography, and cybercrime also children's problem facing the law. To be sure, children are the legal subject that should be protected due to their infancy ${ }^{3}$ in terms of age, physical, and life experience. ${ }^{4}$ This condition puts the children fragile that needs protection.

Since the introduction of decentralization in Indonesia, the local government has been granted local autonomy in managing administration according to the local needs. This idea has then emerged to introduce child protection based on region, like Child-Friendly Cities (KLA). The United Nations Children's Fund (UNICEF) has initiated the Child-Friendly Cities to aspiring children's rights through aims, programs, policies, and local government structures. Indonesia subsequently adopts and establishes them through Regulation of Minister for Women's Empowerment and Child Protection Number 11/2011 on Development Policy of Child-Friendly Cities and Districts. That ministerial regulation then becomes the step-stone for the regional governments to implement child protection. Even at the central government level, the law of child protection has participated in following the regional government's roles with a new spirit as the organizer

1 Article 2. Law No. 35/2014 on the amendment to Law Number 23/2002 on Child Protection.

2 Section. 3. Law No. 35/2014 on the amendment to Law Number 23/2002 on Child Protection.

3 Abintoro Prakoso, Hukum Perlindungan Anak (Yogyakarta: LaksBang Pressindo, 2016) at 35.

$4 \quad$ Ibid at 31. 
parties of child protection. ${ }^{5}$ Thus, the regional government's role becomes strategic in implementing child protection.

The regional governments play an essential role in implementing ChildFriendly Cities. However, no many local governments have set it into the local policy. The Ministry of Women's Empowerment and Child Protection stated only 100 regions in Indonesia have already addressed child protection through local policy. ${ }^{6}$ The local government is supposed to prioritize child protection, realized through Child-Friendly Cities. To date, 40 cities and districts in Indonesia are entitled the Child-Friendly Cities and Districts by the Ministry of Women's Empowerment and Child Protection. ${ }^{7}$ The Ministry stated that there were 328 cities and districts which are categorized as Child-Friendly Cities and Districts. Only two of them have entered the main phase of this category, such as Surabaya and Surakarta. ${ }^{8}$ It asserts that when Child-Friendly Cities and Districts is considered the strategic policy in implementing child protection. Therefore, the government has an arduous task in ensuring child protection in the local government context.

\section{DECENTRALIZATION IN INDONESIA:}

\section{A HISTORICAL CONTEXT}

The fall of Suharto's administration shifted the reformation period that demanded to reconfigure central-local relations resulted in regional autonomy. ${ }^{9}$ The revised 1945 Constitution of Indonesian subsequently

5 Ibid, Article 20.

6 Media Indonesia, "Perda Perlindungan Anak masih Minim" (29 December 2017), online: <https://mediaindonesia.com/read/detail/138381-perda-perlindungan-anakmasih-minim $>$.

7 Republika, “40 Kota di Indonesia Menuju Kota Layak Anak | Republika Online”, online: <https://nasional.republika.co.id/berita/nasional/umum/17/07/13/ot197m40-kota-di-indonesia-menuju-kota-layak-anak>.

8 Republika, "Belum Ada Kota/Kabupaten Layak Anak | Republika Online," online: <https://nasional.republika.co.id/berita/nasional/umum/17/10/19/oy1e0n335belum-ada-kotakabupaten-layak-anak>.

9 Harold A Crouch, Political reform in Indonesia after Soebarto (Singapore: Institute of Southeast Asian Studies, 2010). 
grants regional government autonomy and central assistance. ${ }^{10}$ In short, the explanation about the definition of autonomy itself can be categorized into two, inter alia, restricted autonomy and broad autonomy. ${ }^{11}$ Each region can be specified as restricted autonomy districts, ${ }^{12}$ First, regional affairs are determined categorically, and their development is also arranged in a certain way. Second, if the supervision and monitoring system are well accomplished, the regional autonomy loses its independence in organizing autonomous affairs. Third, the financial communication system between a central and regional government causes several things like restricting the regional government's financial capability to confine the regional government space. It will be different upon the region's broad autonomy in which the usual broad autonomy concept is departed from all government affairs principles and become the regional affairs, except to the things prescribed as central government affairs.

The region can implement local government enforcement based on decentralization and deconcentration. Decentralization is an authorization to arrange and organize the governance to the lower government units. However, since decentralization is always connected with the independence status or autonomy, the discussion about decentralization also means autonomy. ${ }^{13}$ Thus, this decentralization or autonomy principle's primary emphasis is to hand over the central government's full responsibilities to the regional government in certain authorities. Even though the regional government has full regional responsibility, it does not mean such a locality becomes absolute. Instead, there are many other powers retained by the central government.

10 It was amended, Section 18 Article (1) and (2) are: Article (1) The Unitary State of the Republic of Indonesia consists of provinces, and each province has districts and cities, with each province, districts, the city has its regional administration, regulated by law. This regional government shall work its government matters under the principle of regional autonomy and duty to assist.

11 Bagir Manan, Menyongsong Fajar Otonomi Daerah (Yogyakarta: Pusat Studi Hukum FH UII, 2001) at 87.

12 Ibid at 37.

13 Ibid at 140. 
Meanwhile, concerning child protection, it must be seen first to notice deeply and philosophically of child protection itself. One of them is age categorization. In the regional, the age categorization principle for children will produce good regulation for implementing the protection. The child's definition is outlined in the UN Convention on the Right of the Child 1989. Article 1 defines a child as every human being who is below eighteen years old. However, he/she is also given the recognition of different age restrictions that can be applied in national legislation. ${ }^{14}$

Nevertheless, a few states give different restrictions in defining somebody that can be said as a child or adult seeing from age and activity perspective and thinking. In the United Kingdom, criminal liability is given to children who are ten years old, but it is not for political involvement. The children can participate or have political rights when they are already above 18 years old. ${ }^{15}$ In Scotland, children have interval ages $7-15$ years, so they are prosecuted in a juvenile court (young offender's court) on its interval age. Meanwhile, in South Australia, children are 8 to 18 years old, and in Canada, it is under 12 years. ${ }^{16}$

In the United States, twenty-seven states prescribe child's age restriction between 8 and 18 years and other six states conclude it between 8 and 17 years. Other states assumes it between 8 and 16 years. The Netherlands sets between 12 and 18 years as child's age restriction. Meanwhile, Srilanka sets it between 8 and 16 years. ${ }^{17}$

This difference in children's definition in each country is because there is a social influence on child development. The social and cultural activity and economic activity in each country significantly influence each child's maturity level. However, the children's restriction from their age perspective is not always precise. Each person's age condition related to maturity is something pseudo and relative. The reality shows that a child is still

14 Imam Susilowati, Pengertian Konvensi Hak Anak (Jakarta: UNICEF, 2003) at 2.

15 Marlina, Peradilan Pidana Anak di Indonesia (Bandung: Refika Aditama, 2009).

16 Ibid.

17 Paulus Hadisuprapto, Juvenile Delinquency: Pemahaman dan Penanggulangannya (Bandung: Citra Aditya Bhakti, 1997) at 8. 
considered to have limited ability, but that child is already grown-up. Therefore, the maturity determination of someone seen from the age perspective is not precise. According to a psychologist, age maturity cannot be determined by age because there is a younger child but already can think like a grown-up. In contrast, a child is already grown-up but cannot still think like an adult. This psychologist's point of view becomes the issue and big question for all criminal expertise and psychologist in prescribing the age restriction of criminal liability. ${ }^{18}$

Child development consists of several development stages, which can be categorized based on the parallelity of a child's physical development with a child's mental development. Those categorizations are divided into three phases. ${ }^{19}$ The first phase is started when the children are born, from 0 to 7 years, which can be mentioned as an early childhood and mental abilities development stage, body-function development, emotional development, baby language and language meaning for children, and early sexuality development for children. The second phase is begun at an interval of 7 to 14 years, called childhood. It is categorized into the elementary school period for children started at the age of 7 to 12 years, an intellectual period, and early adolescence, pre-puberty early puberty is known as the puerperal period. The third phase is begun on interval age 14-21 years, called adolescence, in real definition, i.e., puberty phase, and adolescence. There is a corresponding period and a transition period of a child becoming a grownup.

Elisabeth B Hurlock elaborated on the classification of age stages of a person connected with the mental development to become four stages, as follows: (a) Child, somebody who is under 12 years old; (b) Pre-adolescence, somebody who is between $12-15$ years old;(c) Adolescence, somebody who is between 15 - 18 years old; and (d) Adult, somebody who is above 18 years. ${ }^{20}$ Meanwhile, Singgih Gunarso suggested the classification of the child to adult development is related with the age and the tendencies of mental

18 Marlina, supra note 15 at 36.

19 Ibid at 7.

20 Kusno Adi, Kebijakan Kriminal Dalam Penanggulangan Tindak Pidana Narkotika Oleh Anak (Malang: UMM Press, 2009) at 5. 
condition, which can be classified into five stages, i.e.: (a) Child, it is somebody who is under 12 years old; (b) Early-teen, it is somebody who is 12-15 years old; (c) Teenager, somebody who is 15-17 years old; (d) Young adult, somebody who is 17-21 years old; and (e) Adult, it is somebody who is above 21 years old. ${ }^{21}$

Each age level has its mental characteristics. The mental development tasks experienced by each somebody's age stages, especially the characteristics of child development, until they reach adolescence. It can be elaborated as follows: (a) child, it is somebody who is under 12 years old, tends to be in the stage of all learning process, starting from learning to differentiate right and wrong, learn physical skills for general games; learn to adapt with friends of the same age. (b) Pre-teen, somebody who is between 12-15 years old. This phase is often called as puberty period, has tendencies like busy to learn mastering his/her body because of the imbalance body size and body inconvenience, high emotion, easy to be offended, anxious, high temper, unconfident, inferiority, and afraid of failing, has a realistic self-concept, hard to be understood, egocentric, loss of social support, tends to be antisocial. Feel bored towards school and social activities, achievement declining in all subjects;(c) Adolescence, the person who has interval age 15 - 18 years, showing the mental tendency like walking in an anomie situation, at which they have to leave his/her childish habits and learn values, patterns, and new behavior (as an adult). ${ }^{22}$

The commitment to give children protection was started when Indonesia ratified the Convention on the Rights of the Child (KHA) in 1990. Reformation, which has been running for approximately two decades, has not shown a significant alteration towards children's protection. It is because of the issues which happened to the children raise instead of declines. Based on child protection cluster, Indonesia Child Protection Commission (KPAI) is categorized 8 (eight) types of cases which have high frequency to befall the children, i.e., social and children are in danger situation, family and emergency nurture, religion and culture, civil right and participation, health

21 Paulus Hadisuprapto, supra note 44 at 9-10.

${ }^{22}$ Kusno Adi, supra note 47 at 6. 
and drugs, education, pornography, and cybercrime and Children's Problem facing the law $(\mathrm{ABH})$. Among those 8 (eight) types, $\mathrm{ABH}$ reaches the first grade in quantity within five years, i.e., 2011-2016, both children as an actor, victim, or witness.

One of the problems which are highlighted to experience increasing is the violence towards children. This increasing trend is found out based on the report from various institutions in several regions like The Civil Registry and Population Agency (Disdukcapil), Women and Children Protection Unit of Special Criminal Investigation Directorate (Ditreskrimum), Integrated Service for Women and Children's Empowerment (P2TP2A), Family Planning and WomenEmpowerment Agency (BKBPP), Family Planning, Community, and Women's Empowerment Agency(BKBPMP), and also Indonesian Child Protection Commission (KPAI). West Nusa Tenggara (NTB), East Java, West Java, and South Borneo are several revealed regions. ${ }^{23}$ Moreover, this kind of case characteristic is like an iceberg phenomenon, i.e., there is a high possibility of many unrevealed cases.

The cases above are a tiny measurement from many cases that happened to the kids. The Indonesian Child Protection Commission (KPAI) has warned that Indonesia is in an emergency of crimes against humanity towards children. A similar statement was stated by the Chairman of the Indonesian Women's Congress (KOWANI), Dr. Giwo Rubianti Wiyogo. He revealed that children have severe problems to gain optimal protection. ${ }^{24}$ If it is reviewed based on children's rights, the children's right to disservice on each cluster will be found out.

For example, related to civil rights, the child has the right to have the birth certificate as a recognition representation of a state for their existence. The birth registration has a strategic role because it is a form of formal recognition

23 Republika, "Laporan Kekerasan Anak di Daerah Meningkat | Republika Online," online: <https://www.republika.co.id/berita/koran/halaman-1/16/11/21/ogzcs315laporan-kekerasan-anak-di-daerah-meningkat>.

${ }^{24}$ Tribunnews, "Permasalahan yang dihadapi Anak dan Perempuan Sepanjang 2017 dalam Catatan Kowani - Halaman 1 - Tribunnews.com", online: <https://www.t ribunnews.com/nasiona1/2017/12/29/permasalahan-yang-dihadapi-anak-danperempuan-sepanjang-2017-dalam-catatan-kowani?page $=1>$. 
to an individual child ${ }^{25}$ Through Law Number 23/2006 on the Population Administration, every child has a right to be reported in an implementing agency where the birth events occur no later than sixty days after the birth. At least fifty million children have not gotten the birth certificate because of administrative fulfillment reasons. ${ }^{26}$ In the part of family and nurture, one of the serious problems is early-age marriage. That early-age marriage in Indonesia is considered high. Indonesia is in the second position in Southeast Asia and $7^{\text {th }}$ grade worldwide. This early-age marriage is disadvantageous for children's rights, especially girls. Their future will be affected. In this case, the child's rights, which are seized, are the right to education, right to livelihood, social-political right, and freedom from violence. ${ }^{27}$

\section{THE RESULT OF THE CHILD PROTECTION IMPLEMENTATION IN THE REGIONAL CONTEXT}

Article 1 of the 1945 Constitution states that Indonesia shall be a unitary state in a republic and based on law. Explicitly, Indonesia is based on the law, not power (machtsstaat). As a result, the government follows the constitution system in fulfilling tasks, not based on absolutism. ${ }^{28}$ Then, in Chapter XA Section 28B states that each child has the right to live, grow up, and develop and the right of protection from violence or discrimination. The constitution guarantees a child's right, which is deserved to be protected and fulfilled. The part in the child's right is the part that becomes sanction if it is separated from the effort delegated to each city/district lived by children. Fear, anxiety, and all of the discrimination forms and legal protection or law

25 KPAI. "'Akta Kelahiran Hak Anak yang Terabaikan," (22 July 2013), online: Komisi Perlindungan Anak Indonesia KPAI <https://www.kpai. go.id/berita/akta-kelahiranhak-anak-yang-terabaikan>.

26 Hukumonline, “Terabaikan, 50 Juta Anak Indonesia Tidak Memiliki Akta Kelahiran”, (23 July 2016), online: bukumonline.com <https:/www.hukumonline.com/berita/ baca/lt5792447bd5551/terabaikan--50-juta-anak-indonesia-tidak-memiliki-aktakelahiran>.

27 Hukumonline, "Pernikahan Dini Dinilai Langgar Hak Anak Perempuan" (16 October 2014), online: bukumonline.com <https:/www.hukumonline.com/berita/ baca/lt543f9219071a8/pernikahan-dini-dinilai-langgar-hak-anak-perempuan>.

28 Simon Nahak, Hukum Pajak Perpajakan: Konsep Penal Policy Tindak Pidana Perpajakan dalam Perspektif Pembaharuan Hukum (Malang: Setara Press, 2014) at 2. 
enforcement towards a child's problem facing the law deserve to be paid attention by State, especially District/City, where children live. Precisely, the regulation issued by the Minister of Women's Empowerment and Child Protection of State of Indonesia has established 2 (two) regulations which the guarantee districts/cities to be able to be concluded as Child-Friendly Cities/Districts, i.e., Ministerial Regulation P3A No. 11/2011 concerning the indicator of Child-Friendly Cities/Districts. It is, of course, synchronized with the condition in each city/district which based on Law Number 32/2014 on The Regional Government (City/District) has had the regional autonomy for implementing the decentralization principle, deconcentration principle, and duty to assist which one of them is to issue the regional regulation about Child-Friendly Cities/Districts.

Within 12 years since the beginning of the Child-Friendly Cities and Districts trial, there are 126 cities/districts which receive the achievement of KLA out of 349 cities/districts that initiate KLA. ${ }^{29}$ Though that achievement status has meant that city/district has not fully gotten status as Child-Friendly Cities and Districts, this achievement is for cities/districts in a stage towards Child-Friendly Cities and Districts. Ironically, The Ministry of Women's Empowerment and Child Protection stated that this time Child-Friendly Cities and Districts in Indonesia is still nil. Meanwhile, the achievement given to Surakarta and Surabaya are categorized in the main category and Denpasar, Gianyar, Padang, Magelang, Depok, Bogor, and Sleman has Nindya category. ${ }^{30}$ The Ministry has the design that, in the year 2030, cities/districts in Indonesia have the status of Child-Friendly Cities and Districts. As a result, the commitment and seriousness become the need from the various party who have roles and participate in fulfilling the child's rights, i.e., government, society, mass media, and the business world.

29 Media Indonesia, "Empat Provinsi Raih Penghargaan Pelopor Provinsi Layak Anak," (24 July 2019), online: <https://mediaindonesia.com/read/detail/248859-empatprovinsi-raih-penghargaan-pelopor-provinsi-layak-anak $>$.

30 Okezone, "Hari Anak Nasional: Ironis! Belum Ada Kabupaten \& Kota Layak Anak di Indonesia: Okezone Lifestyle", (23 July 2017), online: <https://lifestyle. okezone.com/read/2017/07/23/196/1742182/hari-anak-nasional-ironis-belum-adakabupaten-kota-layak-anak-di-indonesia>. 
Carrying predicate as the leading category in Child-Friendly Cities and Districts achievement, stakeholders' struggle in Surabaya and Surakarta deserves to be appreciated. As much as 31 indicators, which are later pursed to become 24 indicators divided into six clusters, must be fulfilled to actualize Child-Friendly Cities and Districts. The first indicator in achieving ChildFriendly Cities and Districts is the institutional aspect. The first point of ministerial regulation of Child-Friendly Cities and Districts states that there are constitutions and policies related to fulfilling a child's rights.

For example, Surabaya is a city that has gotten several achievements as a Child-Friendly Cities and Districts. Since 2011, Surabaya achieves the Madya Category of Child-Friendly Cities and Districts, Nindya Category in 2012, 2013, and 2015. Until 2017, along with Surakarta, Surabaya gets The Achievement of Child-Friendly Cities and Districts for Main Category. At least, the regional government of Surabaya has provided many legal products that are responsive to children. Among them are Regional Regulation Number 6/2011 on The Implementation of Child Protection and Regional Regulation Number 2/2012 on The Children Welfare Implementation. Even the DPRD of Surabaya city intends to complete the Regional Regulation of child protection implementation, which has existed to push the child protection model in the modern era. This regional regulation is present in the era where information technology has not rushed as it does now. ${ }^{31}$ Besides, its presence coincides with the development planning deliberation (Musrenbang) 2018 in order to arrange The Regional Government Work Plan 2019. The mayor of Surabaya, Tri Rismaharini, prioritizes and concerns the child protection with the hope that children will not be victims in the future. ${ }^{32}$

Even in the institutional aspects, Surabaya's regional government provides layering institutions to implement child protection. In the level of kelurahan

31 Tribunnews, "DPRD Minta Perda Perlindungan Anak segera Diperbaharui - Surya," online: <https://surabaya.tribunnews.com/2018/01/26/dprd-minta-perda-perlindung an-anak-segera-diperbaharui >.

32 iNews, "Risma: Musrenbang Surabaya 2018 Fokus pada Perlindungan Anak - iNews Portal", online: <https://jatim.inews.id/berita/risma-musrenbang-surabaya-2018fokus-pada-perlindungan-anak>. 
(administrative village), there is a task force(Satgas) of Women and Children protection, in sub-district, there is Community-Based Crisis Centre (PKBM), and also at the city level, there is Integrated Services Centre for Protection of Women and Children (PPPTP2A). ${ }^{33}$ The regional government of Surabaya along with the Population Control, the Agency of Women's Empowerment, and Child Protection (DP5A), Regional Organization (OPD), Police, Social Services, Public Health Office, National Narcotics Agency (BNN), and another civil society organization (LSM) do the innovations in order to give a better environment for child growth and development. Through the Agency of Women's Empowerment and Child Protection (DP5A), a family learning center (puspaga) has the function as service of family problem resolution until the consultation for the couple who are going to get married. Education is not left behind. Education authority cooperated with the college through Corporate Social Responsibility (CSR) to push dropout rates in part of education. The public area is for children to run their activities like dancing, musical practice, karawitan, and martial training. Also another innovation like nutrition fulfillment and child immunization, the provision of 1400 community reading parks, house of language and house of mathematics, healthy internet program, and also a program of Kampunge Arek Suroboyo, which consists of Education Kampong(Kampung Pendidikan), Safe Kampong (Kampung Aman), Nurture Kampong (Kampung Asub) and also Command Centre as the place for complaining about missing children and suicidal trial. ${ }^{34}$

As the receiver of Child-Friendly Cities and Districts achievement for the main category, it does not mean that Surabaya has no problems with children. The Women and Children Protection Unit of Polrestabes Surabaya is still receiving the report of violence towards children until now. The violence that happened to children is like an iceberg phenomenon. Almost $90 \%$ of violence cases reported are sexual violence in which the crime

33 Possure, "Kota Layak Anak, Mari Belajar pada Surabaya - Aktual Dan Kasual," online: <http://possore.com/2017/01/05/kota-layak-anak-mari-belajar-pada-surabaya>.

34 Detik.com, "Surabaya Dapat Apresiasi Tim Juri Nasional Kota Layak Anak," online: detiknews <https://news.detik.com/adv-nhl-detikcom/d-3523488/surabaya-dapatapresiasi-tim-juri-nasional-kota-layak-anak>. 
actors are their inner circles, people they know. ${ }^{35}$ The violence towards children, which keeps continuing, is later followed-up by stakeholders related to the $\mathrm{OPD}$, society, or other related parties.

The different things that happened in Surakarta, the effort towards ChildFriendly Cities and Districts, not only get appreciation from the Indonesian government but also the Under-Secretary-General of the United Nations the issue of child protection. This international organization also appreciates the steps the Surakarta government chooses. Surakarta, which has received the predicate as Child-Friendly Cities and Districts since 2006 with Madya Predicate. It has a higher rank Child-Friendly Cities and Districts, i.e., the main predicate used as a reference for other cities/districts. Related to the institutional development, Surakarta has local regulation Number 4/2012 on Child Protection. Besides, the regional government of Surakarta initiates and has cooperation with the Ministry of Social Affairs (Kemensos) and UNICEF informing the institution which has a vital role in protecting the children in a regional area, i.e., the Service Centre for Integrative Children Social Welfare (Pusat Layanan Kesejahteraan Sosial Anak Integratif/PLKSAI). Before the PLKSAI was born, there is an Integrated Service for Women and Children in Surakarta (Pusat Pelayanan Terpadu Bagi Perempuan dan Anak Koa Surakarta/PTPAS), but in order to actualize child protection comprehensively and also gives the child social welfare service maximally, so PLKSAI is made. The Head of Child Protection of Bapernas PPPA and KB, Supraptiningsih, stated four primary duties of PLKSAI deals with implementing the complaint service and reference related to social welfare and child protection. These duties also relate to rehabilitation implementation and social reintegration for children and families that experience the social welfare and child protection problem, execute the advocacy related to the child's social welfare, and organize the

35 Radar Surabaya, "Miris! Kekerasan Terhadap Anak Terus Terjadi", online: <https://radarsurabaya.jawapos.com/read/2018/03/04/54153/miris-kekerasanterhadap-anak-di-surabaya-terus-terjadi> . 
data system and information related to social welfare child protection problem. ${ }^{36}$

Child-Friendly Facilities have been provided to support the child's growth and development for children who become violent victims, smart-parks, and half-way houses for HIV/AIDS patients. What makes it interesting is, in the smart-park, provides the children rides for playing and learning, like an amusement park, library, spaces for playing gamelan instruments, ballroom, two amphitheaters, computer learning, a particular radio station for Konata children, and a family learning center (Puspaga). They provide psychology services for parents if they want to have consultation concerning a kid or family. ${ }^{37}$ Child-friendly Community Health Centre (Puskemas), ChildFriendly School, and Child Incentive Card (KIA), in part of transportation it is the existence of safe zone for children and the driving ban for under 17 years old, Child Forum, and breastfeeding corner, GWJB, which is a ban to turn on the TV on Sunday to Friday starting from 18.30-20.30. Also, it becomes a facility by providing child-friendly services in Surakarta.

Generally, the Surakarta achievement as Child-Friendly Cities and Districts in the main category has reached $93 \%$ or $+/-932$ points out of 1000 standard point as Child-Friendly Cities and Districts. Next is the general illustration of the achievement of Child-Friendly Cities and Districts in Surakarta. The institution indicator has reached $100 \%$, and it is even stated over standard, civil right and freedom 98\%, family environment and child nurture 91\%, essential health and welfare $89 \%$, education, free time utilization, and cultural activity reach $95 \%$ and also better protection reaches $89 \%{ }^{38}$ Therefore, the implementation of child protection at regional in an integrated manner and coordination with various elements imply in creating a conducive environment for child growth and development even participate

36 Surakarta Government, "Surakarta Miliki Pusat Layanan Anak Terintegrasi Pemerintah Kota Surakarta," online: <http://surakarta.go.id/?p=4112>.

37 Surakarta Government, "PBB Pun Acungi Jempol Program Anak di Surakarta," (28 February 2017), online: Pemerintah Kota Surak <https://surakarta.go.id/?p=4340>.

38 Surakarta Government, "Surakarta Kota Layak Anak," (24 July 2017), online: Pemerintah Kota Surak <https://surakarta.go.id/?p=6471>. 
in helping to protect and fulfill the children's rights as it is mentioned in KHA and the Law of Child Protection.

\section{CONCLUSION}

As the cornerstone of the regional autonomy, decentralization encourages the establishment of the Child-Friendly Cities and Districts in Indonesia. This establishment has been addressed through several regulations in ensuring child protection in the local context. This local initiative reflects the guidelines set by UNICEF as an international institution that works for children. In practice, however, the limited number of regional governments to address the Child-Friendly Cities has become new vital challenges. These challenges are the administrative affairs, such as the budget system and institutional coordination.

\section{REFERENCES}

Abintoro Prakoso. Hukum Perlindungan Anak (Yogyakarta: LaksBang Pressindo, 2016).

Bagir Manan. Menyongsong Fajar Otonomi Daerah (Yogyakarta: Pusat Studi Hukum FH UII, 2001).

Crouch, Harold A. Political reform in Indonesia after Soeharto (Singapore: Institute of Southeast Asian Studies, 2010).

Detik.com. "Surabaya Dapat Apresiasi Tim Juri Nasional Kota Layak Anak", online: detiknews <https://news.detik.com/adv-nhldetikcom/d-3523488/surabaya-dapat-apresiasi-tim-jurinasional-kota-layak-anak>.

Hukumonline. “Terabaikan, 50 Juta Anak Indonesia Tidak Memiliki Akta Kelahiran”, (23 July 2016), online: <https://www.hukumonline. com/berita/baca/lt5792447bd5551/terabaikan--50-juta-anakindonesia-tidak-memiliki-akta-kelahiran>.

Hukumonline. "Pernikahan Dini Dinilai Langgar Hak Anak Perempuan", (16 October 2014), online: <https://www.hukumonline.com/ 
berita/baca/lt543f9219071a8/pernikahan-dini-dinilai-langgarhak-anak-perempuan>.

Imam Susilowati. Pengertian Konvensi Hak Anak (Jakarta: UNICEF, 2003). iNews. "Risma: Musrenbang Surabaya 2018 Fokus pada Perlindungan Anak - iNews Portal”, online: <https://jatim.inews.id/berita/rismamusrenbang-surabaya-2018-fokus-pada-perlindungan-anak>.

KPAI. “'Akta Kelahiran Hak Anak yang Terabaikan”, (22 July 2013), online: Komisi Perlindungan Anak Indones KPAI <https://www.kpai.go.id/ berita/akta-kelahiran-hak-anak-yang-terabaikan>.

Kusno Adi. Kebijakan Kriminal Dalam Penanggulangan Tindak Pidana Narkotika Oleh Anak (Malang: UMM Press, 2009).

Marlina. Peradilan Pidana Anak di Indonesia (Bandung: Refika Aditama, 2009).

Media Indonesia. "Empat Provinsi Raih Penghargaan Pelopor Provinsi Layak Anak", (24 July 2019), online: $<$ https://mediaindonesia.com/read/detail/248859-empatprovinsi-raih-penghargaan-pelopor-provinsi-layak-anak>.

Media Indonesia. "Perda Perlindungan Anak masih Minim”, (29 December 2017), online: <https://mediaindonesia.com/read/detail/138381perda-perlindungan-anak-masih-minim $>$.

Okezone. "Hari Anak Nasional: Ironis! Belum Ada Kabupaten \& Kota Layak Anak di Indonesia: Okezone Lifestyle”, (23 July 2017), online: <https://lifestyle.okezone.com/read/2017/07/23/196/174 2182/hari-anak-nasional-ironis-belum-ada-kabupaten-kotalayak-anak-di-indonesia>.

Paulus Hadisuprapto. Juvenile Delinquency: Pemahaman dan Penanggulangannya (Bandung: Citra Aditya Bhakti, 1997).

Possore. "Kota Layak Anak, Mari Belajar pada Surabaya - Aktual Dan Kasual”, online: <http://possore.com/2017/01/05/kota-layakanak-mari-belajar-pada-surabaya/>.

Radar Surabaya. "Miris! Kekerasan Terhadap Anak Terus Terjadi”, online: $<$ https://radarsurabaya.jawapos.com/read/2018/03/04/54153/mir is-kekerasan-terhadap-anak-di-surabaya-terus-terjadi $>$. 
Republika. "Belum Ada Kota/Kabupaten Layak Anak | Republika Online", online: <https://nasional.republika.co.id/berita/nasional/umum/ 17/10/19/oy1e0n335-belum-ada-kotakabupaten-layak-anak>.

Republika. "40 Kota di Indonesia Menuju Kota Layak Anak| Republika Online”, online: <https://nasional.republika.co.id/berita/nasional/ umum/17/07/13/ot197m-40-kota-di-indonesia-menuju-kotalayak-anak>.

Republika. "Laporan Kekerasan Anak di Daerah Meningkat | Republika Online", online: <https://www.republika.co.id/berita/koran/ halaman-1/16/11/21/ogzcs315-laporan-kekerasan-anak-didaerah-meningkat>.

Simon Nahak. Hukum Pajak Perpajakan: Konsep Penal Policy Tindak Pidana Perpajakan dalam Perspektif Pembaharuan Hukum (Malang: Setara Press, 2014).

Surakarta Government. "PBB Pun Acungi Jempol Program Anak di Surakarta”, (28 February 2017), online: Pemerintah Kota Surak $<$ https://surakarta.go.id/?p=4340>.

Surakarta Government. "Surakarta Kota Layak Anak", (24 July 2017), online: Pemerintah Kota Surak <https://surakarta.go.id/?p=6471>.

Surakarta Government. "Surakarta Miliki Pusat Layanan Anak Terintegrasi - Pemerintah Kota Surakarta", online: <http://surakarta.go.id/?p= 4112>.

Tribunnews. "DPRD Minta Perda Perlindungan Anak segera Diperbaharui - Surya", online: <https://surabaya.tribunnews.com/2018/01/26/ dprd-minta-perda-perlindungan-anak-segera-diperbaharui> .

Tribunnews. "Permasalahan yang Dihadapi Anak dan Perempuan Sepanjang 2017 dalam Catatan Kowani - Halaman 1 Tribunnews.com”, online: <https://www.tribunnews.com/ nasional/2017/12/29/permasalahan-yang-dihadapi-anak-danperempuan-sepanjang-2017-dalam-catatan-kowani?page $=1>$. 
180 | Child-Friendly Cities and Districts As Human Rights Protection

This page intentionally left blank 